\title{
Zoonotic Infection with Oz Virus, a Novel Thogotovirus
}

\author{
Ngo T.B. Tran, Hiroshi Shimoda, Keita Ishijima, Kenzo Yonemitsu, Shohei Minami, \\ Supriyono, Yudai Kuroda, Kango Tatemoto, Milagros V. Mendoza, Ryusei Kuwata, Ai Takano, \\ Masahiko Muto, Kyoko Sawabe, Haruhiko Isawa, Daisuke Hayasaka, Ken Maeda
}

$\mathrm{Oz}$ virus is a novel thogotovirus isolated from ticks that causes lethal infection in mice. We conducted serosurveillance of $\mathrm{Oz}$ virus infection among humans and wild mammals in Japan using virus-neutralization tests and ELISAs. Results showed that $\mathrm{Oz}$ virus may be naturally infecting humans and other mammalian hosts.

$\mathrm{T}$ genus Thogotovirus, family Orthomyxoviridae, comprises viruses that are most frequently transmitted by a variety of hard and soft tick species (1). Although most thogotoviruses are associated with tick species, there are several exceptions, such as Sinu virus, which was isolated from mosquitoes (2); Dielmo orthomyxovirus, isolated from Culicoides midges (3); and Araguari virus, isolated only from vertebrates (4). Thogoto, Dhori, and Bourbon viruses have been associated with human disease. Thogoto and Dhori viruses have been reported to cause encephalitis, febrile illness, and death in humans $(5,6)$, and Bourbon virus to cause febrile illness and death in humans (7). In addition, Thogoto virus has been reported to cause abortions in sheep (8), and many wild animals are positive for Bourbon virus antibodies (9).

Oz virus, a new member of the genus Thogotovirus, was first isolated from a pool of 3 Amblyomma testudinarium tick nymphs collected in Ehime prefecture, Japan (10). Phylogenetic analyses revealed that $\mathrm{Oz}$ virus is more closely related to Dhori, Batken, and Bourbon viruses than to other thogotoviruses (10). In addition, $\mathrm{Oz}$ virus has been shown to cause

Author affiliations: Yamaguchi University, Yoshida, Japan (N.T.B. Tran, H. Shimoda, S. Minami, Supriyono, A. Takano,

D. Hayasaka, K. Maeda); National Institute of Infectious Diseases, Toyama, Tokyo, Japan (K. Ishijima, K. Yonemitsu, Y. Kuroda, K. Tatemoto, M.V. Mendoza, K. Sawabe, H. Isawa, K. Maeda); Okayama University of Science, Imabari, Japan (R. Kuwata); Yamaguchi Prefectural Grand Medical Center, Hofu, Japan (M. Muto)

DOI: https://doi.org/10.3201/eid2802.211270 lethal infection in experimentally challenged suckling mice. To determine the potential of $\mathrm{Oz}$ virus as a zoonotic pathogen, we performed serosurveillance of $\mathrm{Oz}$ virus infection among mammals, including humans, in Japan.

\section{The Study}

To examine whether mammals are naturally infected with $\mathrm{Oz}$ virus, we collected serum samples from 24 hunters and 240 wild animals (40 Japanese macaques [Macaca fuscata], 124 wild boars [Sus scrofa], and 76 sika deer [Cervus nippon]) captured in Yamaguchi prefecture, Japan, during 2013-2019. Because Yamaguchi prefecture is close to Ehime prefecture and the environment in Yamaguchi is very similar to that in Ehime, we used stocked samples in Yamaguchi prefecture for the first surveillance of $\mathrm{Oz}$ virus infection. To test for the presence of $\mathrm{Oz}$ virus antibodies in the serum samples, we performed a $\operatorname{PRNT}_{80}(80 \%$ plaque-reduction neutralizing test) using $\mathrm{Oz}$ virus (Table 1). Among humans, $8.3 \%$ of the serum samples had $\mathrm{Oz}$ virus neutralization (VN) antibodies; VN titers were 1:40 and 1:80. In wild animals, serum from $47.5 \%$ of macaques, $60.5 \%$ of wild boars, and $73.7 \%$ of sika deer in Yamaguchi had $\mathrm{Oz}$ virus VN antibodies (Table 1).

We applied ELISA protocol used for serosurveillance of many infectious diseases (11-13) to detect $\mathrm{Oz}$ virus antibodies in the serum samples from wild animals. We extracted proteins from $\mathrm{Oz}$ virus or mockinfected Vero cells and used the extracts as ELISA antigens. To prepare the primary antibody, we diluted serum samples 1:100 in phosphate-buffered saline containing $0.05 \%$ Tween 20 and $0.4 \%$ Block Ace. We used peroxidase conjugated recombinant protein A/G (Thermo Fisher Scientific, https://www.thermofisher.com) as the secondary antibody and KPL ABTS peroxidase substrate (SeraCare Life Sciences, https:/ /www.seracare.com) as the detection reagent. We measured absorbance using a spectrophotometer 
Table 1. Serosurveillance of Oz virus infection by virus-neutralization test among mammals in Yamaguchi prefecture, Japan

\begin{tabular}{|c|c|c|c|c|c|c|c|c|c|}
\hline \multirow[b]{2}{*}{ Species } & \multirow[b]{2}{*}{ Genus and species } & \multirow[b]{2}{*}{ Years } & \multicolumn{7}{|c|}{ Virus-neutralization titer } \\
\hline & & & $<1: 10$ & $1: 10$ & $1: 20$ & $1: 40$ & $1: 80$ & $1: 160$ & $>1: 160$ \\
\hline Human & Homo sapiens & 2015 & 22 & 0 & 0 & 1 & 1 & 0 & 0 \\
\hline Macaque & Macaca fuscata & 2018-2019 & 21 & 0 & 2 & 3 & 3 & 6 & 5 \\
\hline Wild boar & Sus scrofa leucomystax & 2013-2014 & 49 & 2 & 12 & 10 & 15 & 20 & 16 \\
\hline Sika deer & Cervus nippon & 2014-2015 & 20 & 5 & 8 & 11 & 12 & 13 & 7 \\
\hline
\end{tabular}

(Bio-Rad Laboratories, https://www.bio-rad.com) with a $405 \mathrm{~nm}$ filter and subtracted the value of the corresponding control mock-infected cells from all values.

To determine ELISA cutoff values, we tested serum samples from the 40 macaques, 124 wild boars, and 76 sika deer captured in Yamaguchi prefecture. We compared the optical density values of the ELISA to the results of the $\mathrm{VN}$ test by 2-graph receiver-operating characteristic (ROC) curve analysis as described elsewhere (14). In macaques, the correlation coefficient between the ELISA and VN test was 0.9163 , and an ELISA cutoff value of 0.2245 produced $100 \%$ sensitivity and specificity. In wild boars, the correlation coefficient was 0.8807 , with $88.0 \%$ sensitivity and $89.8 \%$ specificity at an ELISA cutoff value of 0.1965 . In sika deer, the correlation coefficient was 0.7569 , sensitivity $78.6 \%$, and specificity $80.0 \%$ at an ELISA cutoff value of 0.3165 (Figure 1).

Next, we surveyed $\mathrm{Oz}$ virus infection among macaques, wild boars, and sika deer in many prefectures in Japan using the established ELISA (Table 2; Figure 2). Among 197 macaques captured during 2007-2019, seropositivity rates were $47.5 \%$ in Yamaguchi, 33.3\% in Wakayama, and 6.3\% in Mie prefectures. Among 879 wild boars captured during 2007-2014, seropositivity rates were $10.3 \%$ in Oita, 55.8\% in Yamaguchi, $34.8 \%$ in Wakayama, $10.5 \%$ in Gifu, and $0 \%$ in both Toyama and Tochigi prefectures. Among 450 sika deer, seropositivity rates were $37.8 \%$ in Yamaguchi,
$11.1 \%$ in Wakayama, $8.3 \%$ in Gifu, and 30\% in Chiba prefectures.

First, we applied $\mathrm{PRNT}_{80}$ to detect $\mathrm{Oz}$ virus antibodies in humans and wild animals in Yamaguchi prefecture. The results showed that $60.5 \%$ of wild boars, a major host of $A$. testudinarium, and $73.7 \%$ of sika deer in Yamaguchi prefecture during 2013 and 2015 had Oz virus VN antibodies, indicating that the virus was infecting wild animals in the western part of Japan. Next, we examined wild macaques for $\mathrm{Oz}$ virus infection; $48 \%$ were infected, and the antibody titers were high. In addition, 2 persons who hunted wild boars and sika deer in Yamaguchi prefecture had $\mathrm{Oz}$ virus antibodies. These results indicate that humans and macaques are also exposed to $\mathrm{Oz}$ virus.

We compared results from an ELISA, established for this study, using an $\mathrm{Oz}$ virus-infected cell extract for the surveillance of $\mathrm{Oz}$ virus infection among many mammalians, with those from the VN test to determine correlation between the 2 tests. The correlation coefficient was 0.9163 for macaques, 0.8807 for wild boars, and 0.7569 for sika deer, suggesting that the ELISA is effective for serosurveillance of Oz virus infection in samples from many animal species. However, because its sensitivity and specificity differed among animal species and values were lower for sika deer, in particular, cutoff values should be determined for each animal species. In addition, VN testing should be performed to confirm the presence of $\mathrm{Oz}$ virus antibodies.
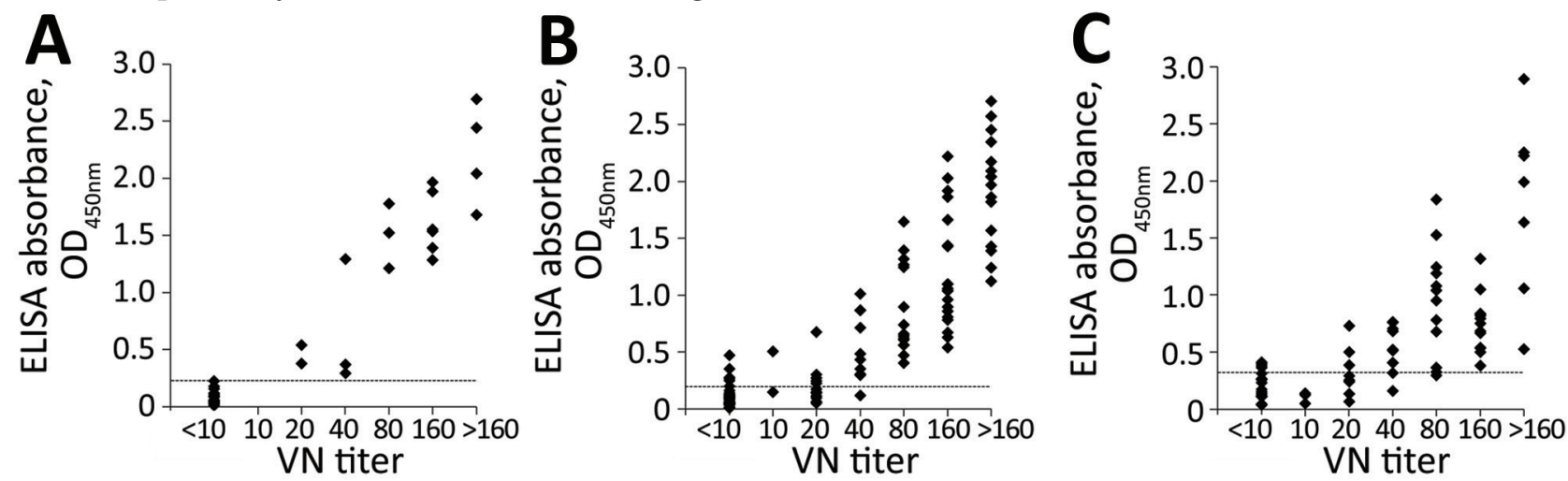

Figure 1. Dot plot comparison between VN test and ELISA against Oz virus in serum samples from wild animals in Yamguchi prefecture, Japan. A) Macaques $(n=40)$; B) wild boar $(n=124)$; C) sika deer $(n=76)$. The correlation coefficient between VN test and ELISA from macaques was 0.9163 , from wild boars was 0.8807 , and from sika deer was 0.7569 . The optimal cutoff value of ELISA was calculated by 2 -graph receiver-operating characteristic curve. The optimal cutoff values were set at 0.225 for macaques, 0.197 for wild boar, and 0.317 for sika deer serum samples and are indicated by dotted lines. 
Table 2. Serosurveillance of $\mathrm{Oz}$ virus infection by ELISA among wild animals, Japan

\begin{tabular}{|c|c|c|c|c|c|}
\hline Species & Prefecture & Years & Cutoff & $\begin{array}{c}\text { No. serum samples } \\
\text { examined }\end{array}$ & $\begin{array}{l}\text { No. (\%) positive } \\
\text { serum samples }\end{array}$ \\
\hline \multirow[t]{3}{*}{ Macaque } & Yamaguchi & $2018-2019$ & 0.225 & 40 & $19(47.5)$ \\
\hline & Wakayama & 2012-2013 & & 15 & $5(33.3)^{\prime}$ \\
\hline & Mie & 2007 & & 142 & $9(6.3)$ \\
\hline \multirow[t]{6}{*}{ Wild boar } & Oita & 2012 & 0.197 & 58 & $6(10.3)$ \\
\hline & Yamaguchi & $2010-2014$ & & 344 & $192(55.8)$ \\
\hline & Wakayama & 2007-2013 & & 89 & $31(34.8)$ \\
\hline & Gifu & 2014 & & 19 & $2(10.5)$ \\
\hline & Toyama & 2014 & & 20 & 0 \\
\hline & Tochigi & 2010-2012 & & 349 & 0 \\
\hline \multirow[t]{4}{*}{ Sika deer } & Yamaguchi & $2010-2015$ & 0.317 & 407 & $154(37.8)$ \\
\hline & Wakayama & $2010-2014$ & & 9 & $1(11.1)$ \\
\hline & Gifu & 2014 & & 24 & $2(8.3)$ \\
\hline & Chiba & 2014 & & 10 & $3(30.0)$ \\
\hline
\end{tabular}

Our nationwide surveillance of $\mathrm{Oz}$ virus infection in Japan indicated that many wild animals were positive for $\mathrm{Oz}$ virus antibodies. However, wild boars in Toyama and Tochigi prefectures did not have $\mathrm{Oz}$ virus antibodies, suggesting that the virus might not be distributed in the northern and eastern parts of Japan. A. testudinarium is the major tick species that infests humans in the southern and western parts of Japan (15), and because we found $\mathrm{Oz}$ virus mainly in those areas, it appears that the distribution of $\mathrm{Oz}$ virus-infected animals correlates with the habitat of the tick. In addition, because 2 hunters in Yamaguchi prefecture tested positive for $\mathrm{Oz}$ virus antibodies, further investigation is needed to determine whether $\mathrm{Oz}$ virus might be a zoonotic pathogen, especially because intracerebral inoculation of the virus in suckling mice causes lethal disease (10).

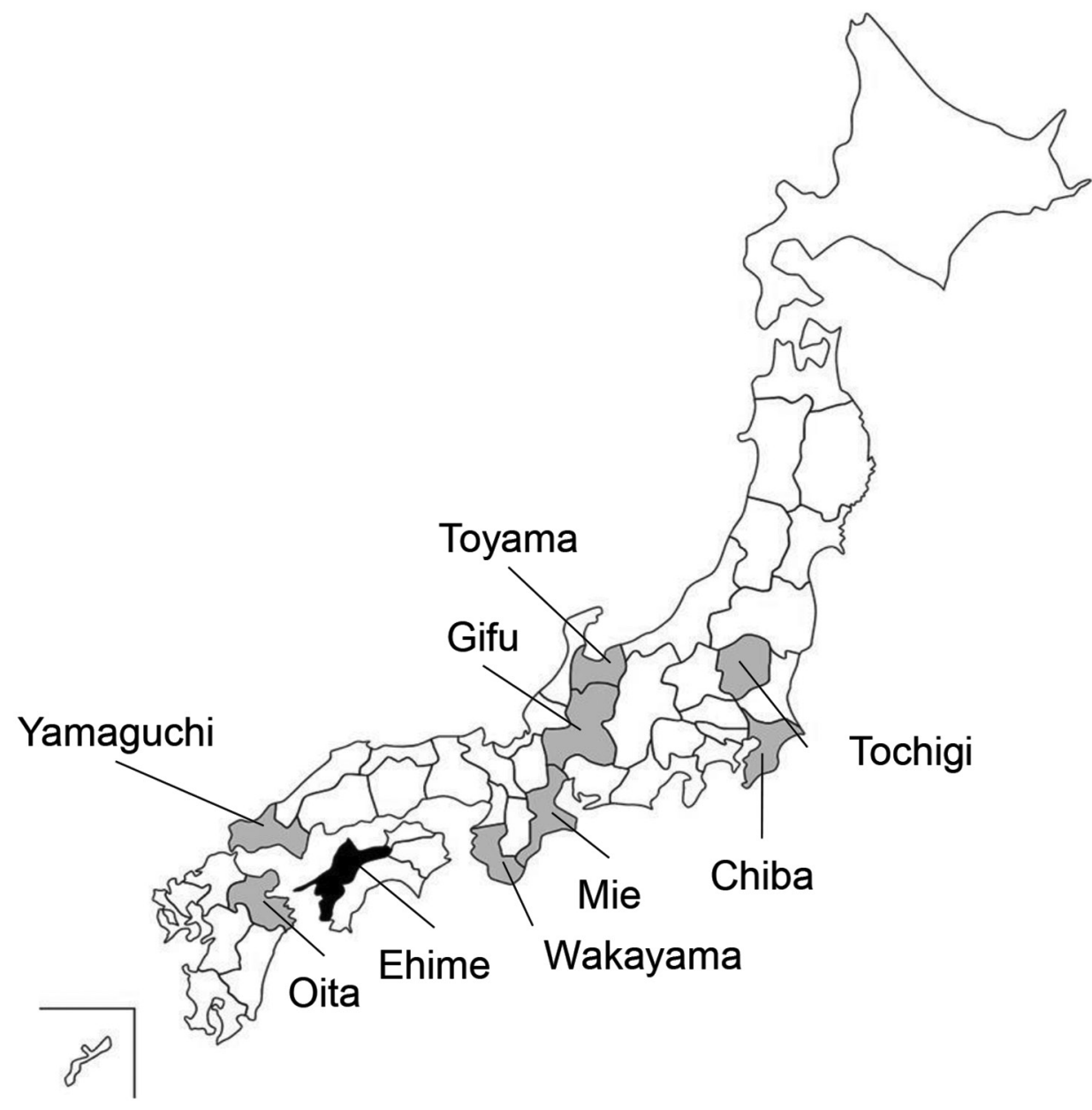

Figure 2. Collection sites of serum samples from macaques, wild boars, and sika deer for study of $\mathrm{Oz}$ virus seroprevalence in Japan. Gray shading indicates prefectures in which samples were collected; black shading indicates Ehime prefecture, where $\mathrm{Oz}$ virus was first isolated. 


\section{Acknowledgments}

We thank Mr. Hashimura and Mr. Matsuzaki for the collection of macaque serum samples, Akiko Nakamura and Kishiko Matsumoto for the collection of human serum samples, Tsutomu Takeda for the collection of wild boar serum samples in Tochigi, Kazuo Suzuki for the collection of serum samples from wild animals, and Toshiya Kimura and Hiroto Shinomiya for advice on $\mathrm{Oz}$ virus infection in Ehime. We also acknowledge all of the hunters who provided support and cooperated with the collection of serum samples.

This study was supported by grants from AMED (Japan Agency for Medical Research and Development) (JP20wm0225009, JP21fk0108613, JP19fk0108097, JP20fk0108067 and JP16fk0108117). N.T.B.T. received a scholarship from the Government of Vietnam Ministry of Agriculture and Rural Development.

All animal samples used in this study were collected with the appropriate hunting permits issued by the respective local government. This article does not contain any studies with live animals. Human serum samples were collected from 24 hunters in Yamaguchi with the approval of the institutional review board of Yamaguchi University (number H26-116).

\section{About the Author}

Mrs. Tran is a PhD student in the Joint Faculty of Veterinary Medicine, Yamaguchi University, Yamaguchi, Japan. Her research interest is zoonoses.

\section{References}

1. Hubálek Z, Rudolf I, Nowotny N. Arboviruses pathogenic for domestic and wild animals. Adv Virus Res. 2014;89:20175. https:/ / doi.org/10.1016/B978-0-12-800172-1.00005-7

2. Contreras-Gutiérrez MA, Nunes MRT, Guzman H, Uribe $S$, Suaza Vasco JD, Cardoso JF, et al. Sinu virus, a novel and divergent orthomyxovirus related to members of the genus Thogotovirus isolated from mosquitoes in Colombia. Virology. 2017;501:166-75. [Erratum in: Virology. 2017;503:114.] https:// doi.org/10.1016/j.virol.2016.11.014

3. Temmam S, Monteil-Bouchard S, Robert C, Baudoin JP, Sambou M, Aubadie-Ladrix M, et al. Characterization of viral communities of biting midges and identification of novel Thogotovirus species and Rhabdovirus genus. Viruses. 2016;8:77. https://doi.org/10.3390/v8030077

4. Da Silva EV, Da Rosa AP, Nunes MR, Diniz JA, Tesh RB, Cruz AC, et al. Araguari virus, a new member of the family
Orthomyxoviridae: serologic, ultrastructural, and molecular characterization. Am J Trop Med Hyg. 2005;73:1050-8. https://doi.org/10.4269/ajtmh.2005.73.1050

5. Moore DL, Causey OR, Carey DE, Reddy S, Cooke AR, Akinkugbe FM, et al. Arthropod-borne viral infections of man in Nigeria, 1964-1970. Ann Trop Med Parasitol. 1975;69:49-64. https:// doi.org/10.1080/00034983.1975.11686983

6. Butenko AM, Leshchinskaia EV, Semashko IV, Donets MA, Mart'ianova LI. Dhori virus - a causative agent of human disease. Five cases of laboratory infection [in Russian]. Vopr Virusol. 1987;32:724-9.

7. Kosoy OI, Lambert AJ, Hawkinson DJ, Pastula DM, Goldsmith CS, Hunt DC, et al. Novel thogotovirus associated with febrile illness and death, United States, 2014. Emerg Infect Dis. 2015;21:760-4. https:/ / doi.org/10.3201/ eid2105.150150

8. Davies FG, Soi RK, Wariru BN. Abortion in sheep caused by Thogoto virus. Vet Rec. 1984;115:654. https:// doi.org/ 10.1136/vr.115.25-26.654

9. Jackson KC, Gidlewski T, Root JJ, Bosco-Lauth AM, Lash RR, Harmon JR, et al. Bourbon virus in wild and domestic animals, Missouri, USA, 2012-2013. Emerg Infect Dis. 2019;25:1752-3. https:// doi.org/10.3201/eid2509.181902

10. Ejiri $H$, Lim CK, Isawa H, Fujita R, Murota K, Sato T, et al. Characterization of a novel thogotovirus isolated from Amblyomma testudinarium ticks in Ehime, Japan: A significant phylogenetic relationship to Bourbon virus. Virus Res. 2018;249:57-65. https:// doi.org/10.1016/ j.virusres.2018.03.004

11. Shimoda H, Inthong N, Noguchi K, Terada $Y$, Nagao $Y$, Shimojima M, et al. Development and application of an indirect enzyme-linked immunosorbent assay for serological survey of Japanese encephalitis virus infection in dogs. J Virol Methods. 2013;187:85-9. https:/ / doi.org/ 10.1016/j.jviromet.2012.09.022

12. Suzuki J, Nishio Y, Kameo Y, Terada Y, Kuwata R, Shimoda $\mathrm{H}$, et al. Canine distemper virus infection among wildlife before and after the epidemic. J Vet Med Sci. 2015;77:1457-63. https:// doi.org/10.1292/jvms.15-0237

13. Yonemitsu K, Minami S, Noguchi K, Kuwata R, Shimoda H, Maeda K. Detection of anti-viral antibodies from meat juice of wild boars. J Vet Med Sci. 2019;81:155-9. https:/ / doi.org/ 10.1292/jvms.18-0576

14. Ikawa-Yoshida A, Yoshii K, Kuwahara K, Obara M, Kariwa H, Takashima I. Development of an ELISA system for tick-borne encephalitis virus infection in rodents. Microbiol Immunol. 2011;55:100-7. https:/ / doi.org/10.1111/ j.1348-0421.2010.00296.x

15. Okino T, Ushirogawa H, Matoba K, Hatsushika R. A bibliographical study of human cases of hard tick (Acarina: Ixodidae) bites received abroad and found in Japan. Kawasaki Med J. 2007;33:189-94.

Address for correspondence: Ken Maeda, Department of Veterinary Science, National Institute of Infectious Diseases, 1-23-1 Toyama, Shinjuku-ku, Tokyo 162-8640, Japan; email: kmaeda@nih.go.jp 